DOI https://doi.org/10.18551/rjoas.2018-09.37

\title{
SOCIAL ASSISTANCE PROGRAM OF LOCAL CULTURE-BASED HOPE FAMILY PROGRAM IN SOUTH JAYAPURA DISTRICT, INDONESIA
}

\author{
Lobo Albertina Nasri* \\ Faculty of Social and Political Sciences, University of Cenderawasih, Indonesia \\ Nurwati Nunung, Binahayati, Gunawan Budhi \\ Faculty of Social and Political Sciences, University of Padjadjaran, Indonesia \\ *E-mail: albertinanasrilobo@yahoo.co.id
}

\begin{abstract}
The implementation of conditional cash transfer gets a serious attention from a number of developed countries as an effective approach to cut poverty and increase long-term social investment for the poor family. However, in terms of multicultural social community, the implementation of Program Keluarga Harapan (Hope Family Program) gives a little attention to the local culture-based sensitivity. This research focuses on the enforcement of local culture-based Hope Family Program in South Jayapura district. This research aims to analyze the implementation of PKH and to determine a local culture-based program implementation. The research design selected was a sequential explanatory design by applying random sampling and purposive sampling technique. Data analysis is emphasized by a qualitative-descriptive analysis. This research result reveals that the implementation of local culture-based Hope Family Program never fully considered the cultural sensitivity of the poor family even though $10 \%$ of the poor family of Hope Family Program beneficiary has said to consider that local cultural sensitivity. This conclusion emphasizes that the implementation of conditional cash transfer assistance to the local culture-based poor family truly influences the achievement of program purpose in a dominant community of socio-culture. Thus, technically, the aspect of cultural competence and cultural sensitivity is important to pay attention to the organization of program implementation.
\end{abstract}

\section{KEY WORDS}

Local culture, cultural sensitivity, cultural competence, hope family program, implementation.

The right to get a better life, an equal recognition and treatment in a homogeneous and heterogeneous collectivity, and inclusively and equitably is a right of every individual, family or even community. Social safeguards is a policy created as a basis of transformation to protect rights of life for marginal, poor, or less privilege community (ILO \& UNDP, 2011). However, the implementation of social policy program does not completely consider the diversity of culture, utilize a local wisdom, and is still centralization and top-down in nature, Kramer (as quoted in Dixon \& Robert, 2002:54.; Hikmat, 2004; Kee, 2007). Meanwhile, cultural diversity and cultural sensitivity is a social resource which can be used by an organization or individual to deliver a social service program (Ife, 2001). Being responsive to the culture is very important in a cultural diversity and multidimensional social problem, as well as a human service organization (Sue, 2001; Lum, 2003; Nybell \& Gray, 2004; Kee, 2007). Since the change of demographics cannot be avoided, even has been started, so the needs of policy, human service program which is responsive to the race, culture, and a minority is increasingly needed (Laenui, 2013).

Social assistance program of the Program Keluarga Harapan (Hope Family Program, hence called as "PKH") is a model of conditional cash transfer, which is for the first time implemented in all provinces, cities/districts in Indonesia, and considered as an effective approach to alleviate poverty. In its execution, PKH chooses the poor family and adult woman group (mother, aunty, grandmother, elder sister) as a target of the program and the coordinator of the grants in the level of the poor family. Patel et al (2013) conclude that the 
social program with a high level of sensitivity in responding gender, woman and children problem, commonly deal with by the poor family, results in a very positive impact.

On the left hand, the use and the utilization of woman as a program coordinator in the family level will give a woman chance to defend his rights and needs, but on the other hands, a cultural obstacle still has a potential to influence responsibility burden as well as woman empowerment and his family. Moreover, in Papua province where the original culture is still applied, a woman plays an important role to drive the control and act jointly as a power to overcome a gap and end poverty (Rumbiak, 2012). As with the number of circulation in the poor family especially managed by a woman, and commonly got by Papuan people is truly low or even does not exist (owned). Even social separation and social gap in a health service for the poor family brings an issue "orang miskin dilarang sakit" (the poor are avoided to be sick), moreover, these two issues do not afford each other, which finally will create treatment options in the poor family, in relation to the awareness level; and economic factor that supports it (Giyai, 2012).

A mutual aid culture, or natural resources dependency and extended family dependency, powerfully influences the dynamics of social life of the People of Papua. Community has a great fear that the conditional cash transfer will shift the habitual basis, belief, value, customs and behavior which has passed over generation, or the other way around, it is positively impacted on the change of dependency habitual, position woman as a weak person, and to relocate the People of Papua (poor family) from the suburb to the downtown to be more competitive with other minority groups (newcomer). Laenui (2013) emphasizes that in order to decrease the gap between target and service, it needs cultural understanding and a cultural-sensitive interaction relationship by all aspects in the organizational chart of humanitarian service. Chambers (2013) in his books entitled Policy Analysis and Social program emphasizes that the understanding and the fulfillment of values underlying social program in the finishing of a social problem is very important. Cultural ability and high sensitivity level of culture helps the achievement of social program purpose in a multicultural community (Lum, 2003; Sue, 2001; Cross, 1998). However, a study of cultural-sensitivity policy or social program is limited, especially in the scope of the people of Papua (the poor family of social program receiver), so this research aims to analyze cultural sensitivity in the implementation of PKH in South Jayapura district of Jayapura City.

\section{LITERATURE REVIEW}

A culture can be understood as a habitual basis, norm, belief, perspective, attitude, William (as quoted in Kee, 2007). It is different from each other. This means cultural has a complex definition. Cultur does not only involve ethnic, race or religion but also includes economic social status (Dell'Osso, 2017). Culture is not static and not constant but able to adapt (Unicef, 2005:1). Cultural essence can be understood as a behavior to influence someone else's attitude and perspective. Laenui (2013) explains that in order to end the gap between target and service, cultural understanding, cultural awareness and a sensitive relationship of cultural interaction is required by all aspects of the organizational chart of humanitarian service. Cultural sensitivity element can be conducted by giving a mentoring pattern that responds the culture (language, perspective, belief, the use of a trusted character). High-level cultural ability and cultural sensitivity helps to reach social program purpose in a multicultural community (Lum, 2003; Sue, 2001; Cross, 1998). A culture can be used as a resource to change behavior (Wang, 2008; Metzeger, et al. 2013). Someone can change his/her behavior when they understand without avoiding its cultural aspect. For that matter, a balance between right and cultural is essential (Sohlberg, 2009). An obligation to do cultural-sensitive advocation is a separated conflict for a social worker (Katiuzhinsky \& David, 2014). Program administration is truly influenced by the organizational chart and culture as well as adhering to the individual activity (Robbins \& Timothy, 2013; Clammer, 2005). Program implementation also depends on the availability of resources (Grindel \& Thomas, 1995; Dinitto, 2015). Actually, all policies and social program commit to increasing someone else's welfare which is less privilege and a retired, but not all implementations in 
the policy and program place the difference of culture in a similar context, so it frequently triggers a conflict. Social program administration needs to consider critical values to overcome social problem at the level of individual, family, and society (Chambers, 2013: 44).

\section{METHODS OF RESEARCH}

This research is designed to use mix methods research (combination) approach. The use of a quantitative and qualitative method supported each other, in which a quantitative method is carried out in advance to then follow up the data in qualitative research which is commonly known as sequential Explanatory Design (Creswell \& Plano Clark, 2007). Simple random sampling and purposive sampling are a technique used to determine sample and informant. The sample is determined based on the database of $\mathrm{PKH}$ receiver, it is then selected based on the research object, with the sample measure of $100 \%$ homogenous, so the representative sample was chosen, which 50 respondents is. In order to support qualitative data is conducted data triangulation to follow qualitative data. Data collecting technique is carried out by several techniques i.e. observation, structured interview, literature review, and documentation. While the data collection tool uses questionnaire and interview guidance. Data analysis technique uses Miles and Huberman, et.al (2014) approach.

\section{RESULTS AND DISCUSSION}

Characteristic of the People of Papua is commonly a collection of Melanesia race. They administratively inhabit all areas of city/district in Papua Province since the first and can be said as a majority society. Every individual or society with his/her social structure inhabits his/her each area. A part of the area is also inhabited by a newcomer which is commonly called Amber and as a minority society. A group of newcomer comes and colors the dynamic of the population in Papua, through spontaneous transmigration activity and managed by the central government, with the aim to improve a better life. The principle is that social relationship is not limited to the area, but being built based on the needs of helping each other, but gradually is shifted to the stream of an individualist culture.

The phenomena of urbanization, centralization and development collapse between city and village as well as the social gap create a cubicle in society. A community cannot freely interact and develop a unique characteristic to fulfill the needs of socio-economic. A society with its all limitation is economy, social, knowledge, skill, ideology, will geographically face a marginalized phenomenon in a society. As what happened, that the majority people in Papua, which is the poor family, are more marginalized to the suburb, as a result of that limitation and the domination of a minority group (newcomer) which almost has an adequacy at all aspects of life. There are $65 \%$ of PKH beneficiary who chose inhabit in the suburb, since they have hak ulayat (indigenous land rights) and limitation in the aspect of life, and other $35 \%$ survive and blend with newcomer, since having no hak ulayat in the suburb. Hak ulayat is only owned by those having outward and inwards relationship, a passing generation with a certain area. This group (a newcomer group) is commonly a group of society conducting urbanization method (local comer), laid on a willingness for having a better life in another region.

A life in an urban area (subdistrict capital) has no negative influence on the family's socio-culture life of PKH beneficiary. A system of cultural value like mutual aid activity, big responsibility to the family bonding, and selections alternative of problem-solving behavior faced are still maintained. There is $95 \%$ family of PKH beneficiary which truly maintains that socio-economic activity. This is due to the social interaction relationship which is very limited to the newcomer. Besides, regulation, value, and belief have a social sanction, so if it is violated the sanction on termination of social and social identity given to the family and family member. PKH beneficiary family which has long inhabited an urban area said that they make an effort to preserve culture they hold, by participating in a extended family cultural event, like marriage, death, education, and health of the extended family, but the size of donation 
(money) is less, changed with the availability of power, time and idea, which is commonly able to reach by PKH beneficiary family.

The implementation of the social assistance of the $\mathrm{PKH}$ conducted nationally since 2007 has impacted on the poor family, especially in the area of the district government in South Jayapura. The implementation of PKH since 2011/2012 involves the central government institution and local government through the social department, and public service institution: Post Office and Bank. Facilitator involvement as the main actor becomes an important factor in the program implementation. The $\mathrm{PKH}$ implementation for the poor family (especially community in South Jayapura) gives a positive different color for the fulfillment of basic needs and problem-solving which is dealing with by. A number of social experts like Griendle (1997); Spieker (2004) say that the implementation of a policy is a benchmark of policy purpose achievement, even Chambers (2013) says that the implementation of policy/social program that considers adequacy, efficiency, and effective aspect, relates to the behavior changes of a program target, is a factor of social program success. Different from Laeni (2013), cultural-renponsive organizational chart decides the success of a policy implementation/humanitarian service program.

The implementation of PKH in the level of South Jayapura district aims to help decrease the poor family's expenses, to increase active participation to the basic service access and to determine poverty transfer among generations. One characteristic of PKH beneficiary family is, among other things, as a common society with a low level of the economy, society who is opened to the changes. While poverty category, program beneficiary family is a family with poverty characteristic caused by the structural design of social, economy, politics, ideology, and individual. Based on the views of life on poverty, PKH beneficiary family is a family having an ability to plan, but the characteristics of dependency and limitation of access become an obstacle to becoming a surviving family.

If considered from the habitual basis and the poverty family's belief in Papua in general and the family of $\mathrm{PKH}$ beneficiary in particular, the implementation of $\mathrm{PKH}$ is considered as an implementation model which does not only give financial model and social model, but also create an earlier self-awareness of a poor family with the existence of social potential in the living area, which can be utilized to increase his/her family welfare. In addition, the implementation of $\mathrm{PKH}$ gives an impact on social interaction which is largely opened to the poor family, which previously is very limited and tends to be closed.

Around $3 \%$ of the beneficiary family says that a grant of cash transfer and a conditional cash transfer create a less-educated behavioral culture, since building a form of expectation/dependency on government assistance, create a habit of "asal bapak senang" (as long you are happy). It is not realized that a half of PKH beneficiary family acted as that, they can force a family member to fulfill commitment on the program. Whereas, the impact made from that characteristic and behavior causes an apparent self-awareness and conflict among family member. But not all PKH beneficiary family see that the grant of conditional cash transfer to the poor family does not produce a high level of dependency culture. By the granting of conditional cash transfer, they increasingly know that the value of any assistance is very high. Thus, they have to change their perspective and life pattern on the helplessness and poverty to keep getting conditional cash transfer. PKH beneficiary family also states that being ready to receive a program means to be also ready to receive all forms of requirement required by $\mathrm{PKH}$ program. Requirement value in $\mathrm{PKH}$ program is accepted by $\mathrm{PKH}$ beneficiary family as a regulation that they have to obey, as regulations which apply in the community. Requirement value is not considered as a full bonding regulation but a regulation which forms a characteristic, attitude and behavior that tend to depend on the availability of resources.

The grants of conditional cash transfer in the form of physical (money) during one year are considered as an approach which does injury money value in a local culture. Material value (money) in a PKH beneficiary family is very high because aside from a solution for basic life needs fulfillment, it also serves as a determiner of a social status level of individual and family. Money value received as a social assistance does not change perspective among the family of PKH beneficiary that they are a family with low social status. Value of 
benefits of $\mathrm{PKH}$ grant is not different from one family to another. Grant is commonly utilized to fulfill the basic needs like clothing, foods, and shelter. An interesting thing found in the aspect of $\mathrm{PKH}$ grants beneficial is it does not change the culture of life pattern in utilizing money. In the meaning of the grant received will only last for hours and days. PKH beneficiary family never had a consciousness to utilize money based on the needs category expected from the program. A life pattern that tends to be temporal in the event of PKH grant utilization is a habitual basis which can be found at all PKH beneficiary families. An awareness to save and leave money at home during days is truly low. This is due to the life needs which are more interesting in the family of PKH beneficiary. In addition, customs and behavior can fulfill the social needs (interesting and grateful) for the nuclear family member and part of multiple family members. Therefore, the granted of cash money annually does not fully have a positive influence on the culture (habitual basis and behavior) of PKH beneficiary family, especially to the level of money value benefits for long-term life needs.

The utilization of adult woman in the poor family by $\mathrm{PKH}$ program is positively responded to by the PKH beneficiary family. A woman in the PKH beneficiary family does not feel the multiplication of task burden and responsibility by the country to him. This condition represents Molyneux's (2004) understanding of the impact of conditional cash transfer for a woman. There were also no widespread rejections from family members regarding the choice of a woman of PKH grant receiver. Position and role of woman in a PKH beneficiary family are very important. They are a foundation and pillar for the welfare of a family member. Thus, it is not uncommon to find that a woman in a family can relax or be at home all day without doing livelihood activities outside the home. Commonly, women working outside the home with long working hours is only to fulfill the basic needs of their families. With the PKH program, women in PKH beneficiary families can feel the different treatment from male family members. The treatment was in the form of an appreciation of women role value (mothers). Mothers are considered useful not only with the work done outside the home, which generates some money, but also as a partner in managing education and health services for family members (children), partners in caring for and raising children, partners in terms of resolving conflicts in the family, which generally never occurred in $\mathrm{PKH}$ beneficiaryy families.

This position is enough to change the way women view themselves and their roles. A culture that has branded itself as one of the less calculated groups in the family experiences a more positive shift in meaning. By getting the full opportunity in the PKH program, the tendency to position themselves as equal partners with male family members can be slowly carried out by women in PKH beneficiary families. There are no rejections received from other family members. A culture that restrains and positions women lower will experience a slight shift, but this situation still has a very high level of tendency to return to previous cultural patterns. This is because the implementation period of the PKH program is limited, and the culture hold by the people of Papua positions boys (men) as a very important and special one in the family. In this case, the implementation of PKH does not change the sociocultural structure which is owned by PKH beneficiary families who position women lower than other family members but create a culture that can receive and work together to achieve a better level of family welfare.

The process of socialization and recollection, to technical assistance in the PKH assistance program, has not fully utilized local resources. Like utilizing the existence and influence of indigenous community leaders to encourage PKH beneficiary families to use the program appropriately. This then leads to rejection of other families who are not recipients of the program. In addition, the utilization of local resources as people who have the power to influence, and have a general information on the cultural characteristics of PKH beneficiaries family are not utilized in PKH companion meetings. In fact, a companion must have an understanding, awareness and cultural ability, which is sufficient to start mentoring with different cultural characteristics (Sue, 2001; Kee, 2007). The inability to transfer program objectives into a simple cultural understanding, so that it is easy to understand and stick to, due to language constraints, makes the program mentoring process seem to fulfill program administration requirements. Whereas with local culture-based assistance, changes in 
behavior, attitudes and knowledge become important (Lum, 2003, Patel, et.al, i 2012; Laeni, 2013). By having a high awareness to start overcoming family problems, which has an impact on access to basic services such as education, health, the families of $\mathrm{PKH}$ beneficiaries actively participate in fulfilling their commitment to the $\mathrm{PKH}$ program.

\section{CONCLUSION}

The implementation of a local culture-based $\mathrm{PKH}$ gives a chance to create an awareness of the importance of long-term human social investment. A commitment of program administrator and program receiver to get a better welfare is a value and special strategic to promote awareness, knowledge, and skill in every form and regulation of PKH program service. When giving socialization of $\mathrm{PKH}$ program benefits service to the family of PKH beneficiary with different cultural characteristics, cultural competency and responsive service will finally help to achieve program purpose, as well as decreasing social, conflict, and social gap conflict that has been already felt by family of PKH beneficiary, before the existence of $\mathrm{PKH}$ administration, as an effective approach to decrease poverty. PKH implementation enlargement which is responsive to the local culture becomes very important.

\section{REFERENCES}

1. Giyai, Aloysius. 2012, Memutus Mata Rantai Kematian di Tanah Papua, Bercermin Pada Fakta RSUD Abepura, Abepura: Papua Pustaka Raya (PAKAR)

2. Chambers, Donald E. 2013. Social Policy and Social Programs A Methods for the Practical Public Policy Analyst Thrid Edition. London: Allyn and Bacon

3. Chien Wang, Y. 2008. A Systematic Evaluation of Culturally Sensitivite HIVIAIDS Preventing Intervention in the US, 1996 - 2007. A Dissertation Submitted to Sosiologi Michigan State University.

4. Clammer, J. 2005. Culture, Development, and Social Theory; On Cultural Studies and the Place Of Culture In Development. UK: Routledge Taylor.

5. Creswell, J. 2014. Research Design Qualitative, Quantitative, and Mixedd Methods Methods Approach. Four Edition. California:Sage Publication

6. Cross. T. 1989. Towards a Culturally Competent System of Care. CASSP Technical Assistance Center. Georgetown Universitu Child Developemtn Center. Washington. PP (3-21).

7. Davies, O. 2008. Rights and revelation: Study of particularism and universality in the advocay of human rights. New Balckfrians, 89 (1022), PP. 441-467

8. Dell'Osso, D.L., 2017. Cultural Sensitivity in Healthcare: The New Modern Day Medicine. Dominican University of California. San Rafel.

9. Dinitto, D.M. \& Cummins, L.K. (2005). Social Welfare Politics And Public Policy Sixth Edition. UAS: Pearson.

10. Dixon, J.,\& Scheurell, R.P. 1995. Social Welfare with Indigenous People. New York: Simultaneously

11. Grindle, M.S. (1980). Politics and Policy Implementation in the third World (M.Grindle, Ed.) New Jersey: Princenton University Press

12. Grindle, M., \& Thomas, J. (1995). Public Choices and Policy Changes: The Political Economy Of Reform in Developing Counteries. Baltimore and London: The Jhon Hopkins University Press.

13. Hikmat, H. (2004). Strategi Pemberdayaan Masyarakat. PT. Graha Grafindo

14. Ife, J. (2001). Local and global practice: Relocating social work as a human rights profession. European Journal of SocialWo r k,4(1), 5-15

15. Ife, J. \& Tesoriero, F. (2008). Community Development. Alternatif Pembangunan Masyarakat di Era Globalisasi. Yogyakarta: Pustaka Pelajar.

16. ILO \& UNDP (International Labour Organization \& United Nations Development Programme), 2011. Sharing Innovative Experiences: Successful Social Protection Floor Experiences, ILO \& UNDP, New York. 
17. Kee, L.H. 2007. Pribumisasi Pekerjaan Sosial: penelitian dan praktek di Sarawak. Yogyakarta: Samudara Biru (Anggota IKAPI)

18. Laenui, Poka. (2013). Cultural Sensitivity in Delivery of Social Services. Jounal of Indigenous Social Development. Volume 2. Issue 1 September. PP (1-9)

19. Lum, D. 2000. Cultural Values and Minority People of Colo, A process: stage Approach. The Journal of Sosiology \& Social Elfare, Volume 22 Issue 1 March 2015. California State University, Sacramento. Pacific Graven, CA: Brooks Cole

20. Katiuzhinky A. \& Okech, D. 2014. Human Rigths, cultural practices, and state policies; Implications for global social work practice and policy. International Journal Of Social Welfare. ISSN 1369-6866. PP (80-88)

21. Isha, M., Cooper, S.M., Zarrett, N., Flory, K. (2013). Culturally Sensitive Risk Behavior Prevention Programs for African American Adolescents: A Systematic Analisis: Clin Child Fam Psychol Rev (2013) 16:187-212, Springer Science + Bussines Media New York

22. UNICEF, UNDES, UNCTAD, ILO, ECA. (2015). Social Protection a Development Priority in the post 2-15 UN Developemnt agenda.

23. Miles, M.B. \& Huberman, A.M. 1992. Analisis Data Kualitatif: Buku Sumber tentang Metode-Metode Baru. Translated by T.R. Rohidi. Jakarta: Universitas Indonesia Press

24. Nybel, LM., \& Gray, S.S. (2004). Race, Place, Space: Meaning of Cultural Competence in Three Chill Welfare Agencies. Social Work, 49(1), 17-26.

25. Patel, L. 2012. Poverty, gender and social protection: Child Support Grants in Soweto, South Africa. Journal of Policy Practice 11(1-2), 106-20

26. Patel, L., Hocfeld, T. \& Moodley, J. 2013: Gender and Child Sensitive Social Protection in South Africa. Development Southern Africa, Vol.30,No. 1, 69-83,

27. Robbins, S.P., Pranab C., Edward R.C. (2012). Contemporary Human Behavior Theory A Critical Perspective For Social Work Third Edition. Allyn \& Bacon

28. Sohlberg, P. (2009). Is there nothing beyond postmodernism and "the theoretical other"? The need for balancing universalism and diversity in social work. International Journal of SocialWelfare,18(3), 317-322.

29. Sue, D.W. (2006). Multicultural Social Work Practice. USA: John Wiley \& Sons, Inc. 